\title{
An Integration of "Online Interactive Apps" for Learning Application of Graph Theory to Enhance Creative Problem Solving of Mathematics Students
}

\author{
https://doi.org/10.3991/ijim.v14i12.15583 \\ Sapti Wahyuningsih $\left.{ }^{(}\right)$,Darmawan Satyananda, Abd Qohar \\ Universitas Negeri Malang, Malang, Indonesia \\ Sapti.wahyuningsih. fmipa@um.ac.id \\ Noor Azean Atan \\ Universiti Teknologi Malaysia, Johor, Malaysia
}

\begin{abstract}
An Integration of "Online Interactive Apps" for learning can be a disruptive learning innovation in higher education. The material of the application of graph theory course has application topics in the real world. How students use the application can be used as a measure of creative problem solving. Mixed method was used in the study. The first phase of the study used one group non-randomized design pre-test and post-test. Participants were students who took courses in the application of graph theory. The second phase of the study involved an exploration of creative problem solving performance through qualitative interviews. Analysis of problem solving skills with creative problem solving instruments adapted from the CPS version 6 . The average performance of students is very good in exploring data and building acceptance, performance is good in generating ideas and designing processes. Finding from this research is a significant improvement of students' Creative ProblemSolving by integrating learning the application of graph theory with "Online Interactive Apps". The results obtained that $69 \%$ of student opinions strongly agree on learning activity can improve creative problem solving. The implementation of "Online Interactive Apps" can be used as an alternative to disruptive learning innovation in mathematics teaching-learning.
\end{abstract}

Keywords-Online Interactive, graph theory, creative problem solving, powtoon applications, and kahoot application.

\section{Introduction}

\subsection{Background}

The development of technology is so rapid in various fields including the educational revolution in higher education. The challenges of the development of information technology lead to challenges in the education world and even require disruptive innovations in higher education. Integrating information technology in learning 
becomes a necessity. There are many computer or online application programs can be used in the integration of online interactive learning. Online learning research in higher education continues to be carried out by researchers worldwide. Innovative online learning can be read on [1], the effectiveness of online learning [2], [3] and efficiency and effectiveness of online learning [4] and online learning in developing countries [5]. Implementation of online collaborative [6], online assessment [7], mobile learning applications for android [8] and model assessment in online courses [9].

Learning innovation by integrating ICT into learning is needed to keep up with the development of education 4.0. Learning will be more effective and efficient by integrating ICT. Research on integrating ICT in learning can be seen in [10]. The integration of ICT can be in the form of interactive leaning. Interactive learning can be seen in [11], [12], [13], and [14]. The use of ICT in learning mathematics can be seen in [15], [16], [17], [18] and [19]. Online learning is also associated with increasing problem solving abilities such as the effect of web learning on problem solving strategies [20], CPS on blended learning seen in [21], [22]. Other studies linking creativity with the development of ICT, for example creative through ICT can be seen in [23] and [24]. Integrating mobile applications to improve creative thinking can be seen in [25] and adoption of mobile applications as learning tools for higher education [26]. While the development of creative learning with e-learning can be seen in [27] and [28].

Material application of graph theory has a wide field of application in real life. The integration of ICT is needed in the implementation of learning the application of graph theory. By identifying the application of graph theory in real life can be used as a tool to measure students' problem solving competencies. Many researchers link problem solving competencies with creativity through online education. Research on the effects of CPS on university students can be seen in [29]. Whereas [30] use CPS for mathematics education. Research on the implementation of CPS in blended learning was conducted by [22] and [21].

Problem solving in lecturing the application of graph theory is obtained from direct experience of students in solving problems in related industries / institutions. From direct experience in the field, students present problems, model in graphs and determine appropriate methods to solve the problem. Based on research noted in the previous paragraph, the use of technology will be able to increase creativity and help solve real problems. Currently, studies that related to the findings are considered very limited in improving creative problem solving of mathematics student in higher education. There is no published data on an integration of "Online Interactive Apps" for learning graph theory application course. How to improve the performance of creative problem solving math students by integrating an online interactive app? How to describe the criteria of the CPS component for mat students in learning the application of graph theory? and what are the student's perception of creativity by implementing an interactive online app in learning the application of graph theory? That is what will be discussed in this article. 


\section{Methods}

Mixed method was used in the study. The first phase of the study used a one group pre-test post-test non-randomized design. The second phase of the study involved an exploration of creative problem solving performance through qualitative interviews. Participants were students who took courses in the application of graph theory $(\mathrm{N}=$ 29 , male $=8$, female $=21$ ) in the even semester 2018-2019. The students' quantitative data were collected in the form of pretest and posttest using Kahoot application. The instrument test was validated by an expert. In the other side, the qualitative data were collected from problem solving task of a real problems in the form of short videos based on Powtoon applications. Qualitative data were taken from task-based interviews, using a semi-structured format. The instruments of the research were taken problem solving skills with creative problem solving instruments adapted from the CPS version 6 [28]. Quantitative data analysis using the Minitab program. Qualitative data analysis are analyzed in some points: categorization, reduction, exploration, interpretation, and drawing conclusion.

\section{$3 \quad$ Results}

\subsection{The CPS mathematics student performance}

The CPS model version 6.1 which includes four indicators main steps (understanding the challenge, generating ideas, preparing for action and planning your approach) with eight indicators minor steps. Analysis of the data for the first research question "how to increase CPS mathematics student performance by integrating an interactive online application?" A kahoot-based interactive application was used in pretest and posttest. The result of normality test for the pretest can be seen in Diagrams 1. The results of the analysis with the application of the Minitab program found that $\mathrm{p}<0.05$, it can be seen in Table 1. This shows that there is a significant increase in CPS mathematical performance of students by integrating an interactive online application. 


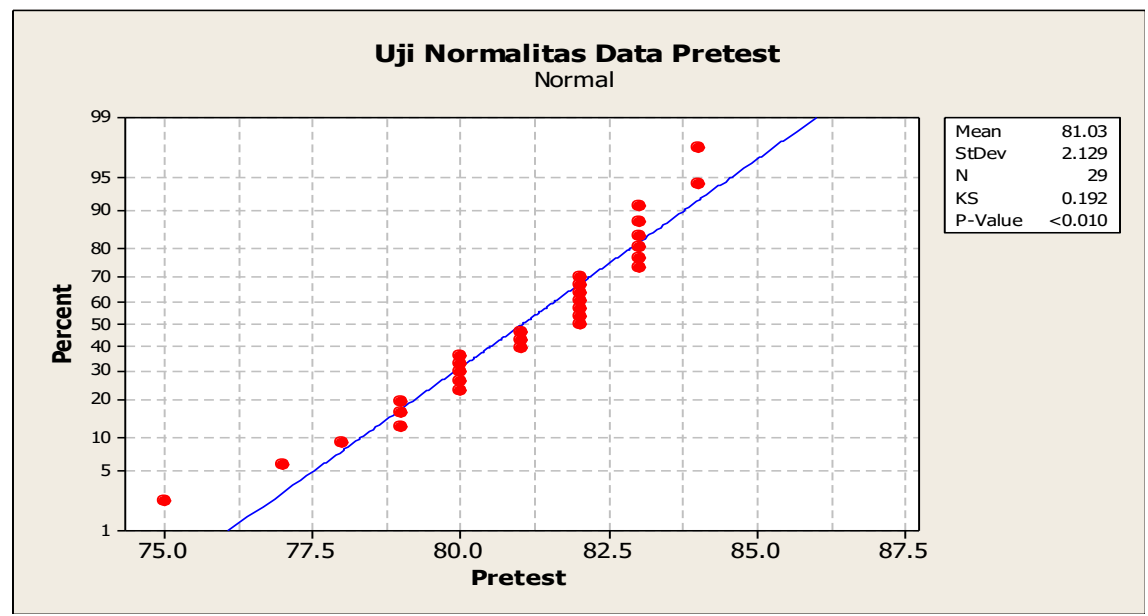

Fig. 1. Normality test

Table 1. Statistics result

\begin{tabular}{|l|c|c|c|c|}
\hline & N & Mean & St Dev & SE Mean \\
\hline pretest & 29 & 81.034 & 2.129 & 0.395 \\
\hline posttest & 29 & 85.862 & 2.100 & 0.390 \\
\hline
\end{tabular}

95\% upper bound for mean difference: -4.049

$\mathrm{T}$-Test of mean difference $=0(\mathrm{vs}<0)$ : T-Value $=-10.55 \mathrm{P}$-Value $=0.000$

3.2 The description of the components of the CPS indicator for mathematics student (CPS version 6)

Analysis of the data for the second research question "how is the description of the components of the CPS indicator for mathematics student performance in learning the application of graph theory?" shown in Diagram 2 to Diagram 5. This shows the average performance of students is very good in exploring data and building acceptance, but performance is good in generating ideas and designing processes 
Paper-An Integration of "Online Interactive Apps" for Learning Application of Graph Theory to.

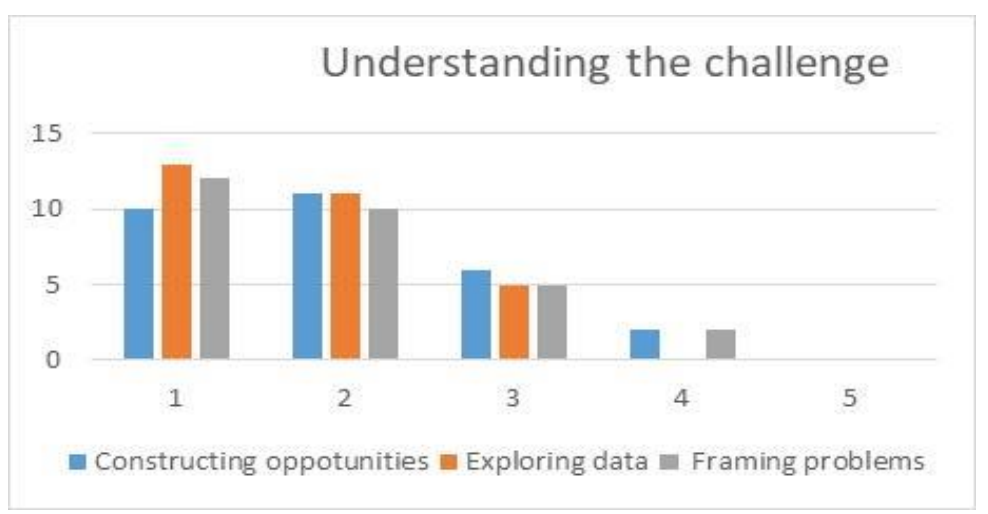

Fig. 2. Understanding the Challenge

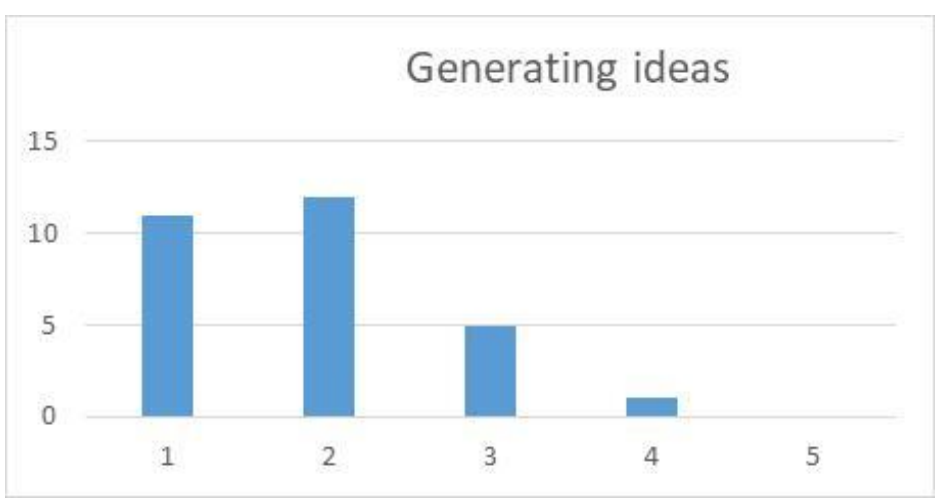

Fig. 3. Generating ideas

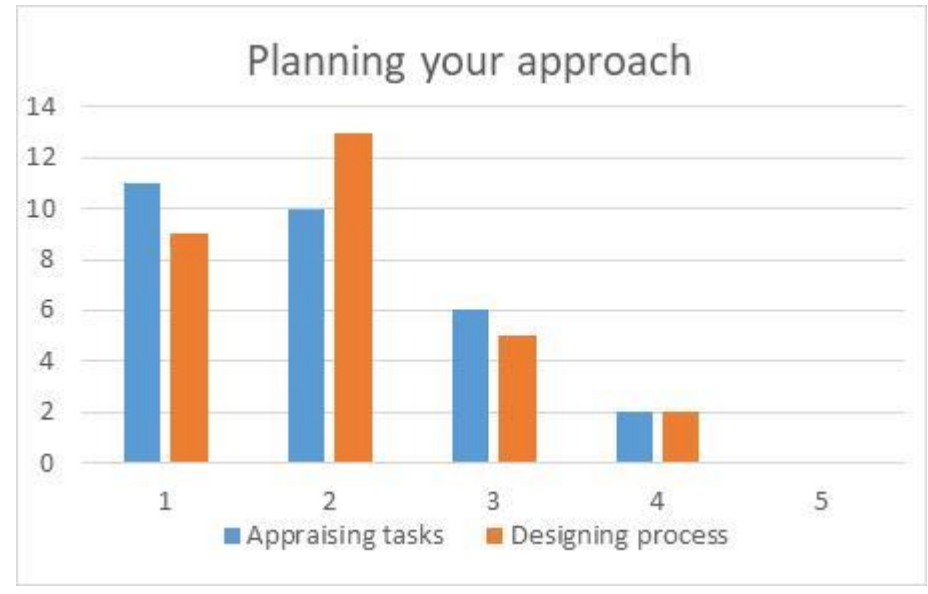

Fig. 4. Planning your approach 


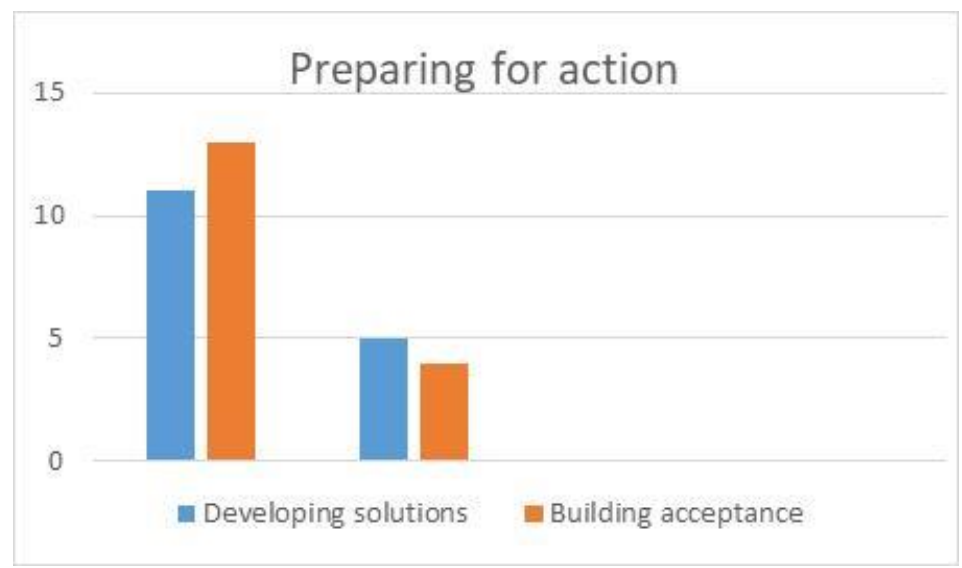

Fig. 5. Preparing for action

\subsection{The student's perception}

Data for the third research question "what is the student's opinions of creativity by implementing an interactive online app in learning the application of graph theory?" is analyzed by giving a questionnaire. Diagram no 6 shown that $69 \%$ of student opinions is very agree on learning activity can improve creative problem solving.

\section{Learning activities can improve creative problem solving}

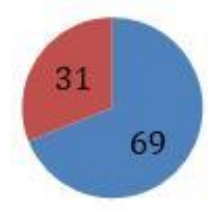

Very agree

(\%)

Agree (\%)

Fig. 6. Students opinions

\section{Discussion}

Integration of "Online Interactive Apps" in pre-test and post-test of this learning was using the Kahoot application. Based on the graphic in Diagram 1 of the pretest and post-test with the probability plot normality test, it can be seen that the points are approaching the diagonal line. It was concluded that the residual value was normally distributed. The normality assumption for the pre-test and post-test values applies so that statistical analysis can proceed to the analysis of Enhance Creative Problem Solving of Mathematics Students in the integration of "Online Interactive Apps". 
The instrument for observing CPS performance of mathematics students was adapted from CPS version 6 [29]. The indicators of main steps and minor steps of the CPS model in the implementation of learning the application of graph theory are 1. Understanding the challenge (building problems in field surveys, exploring real data, problem modeling/designing real problem solving), 2. Generating ideas (compiling and design solutions with algorithms), 3. Preparing for action (developing problem, building acceptance of solutions), and 4. Planning your approach (checking the results of completion, designing process solutions and their interpretation).

The integration of "Online Interactive Apps" used in this study is a powtoon application. Field survey reports in the form of problem modeling, design solutions with algorithms, problem solving with program tools and real problem interpretation are visualized in the powtoon application. An example can be seen in the figure 1 to figure 6.

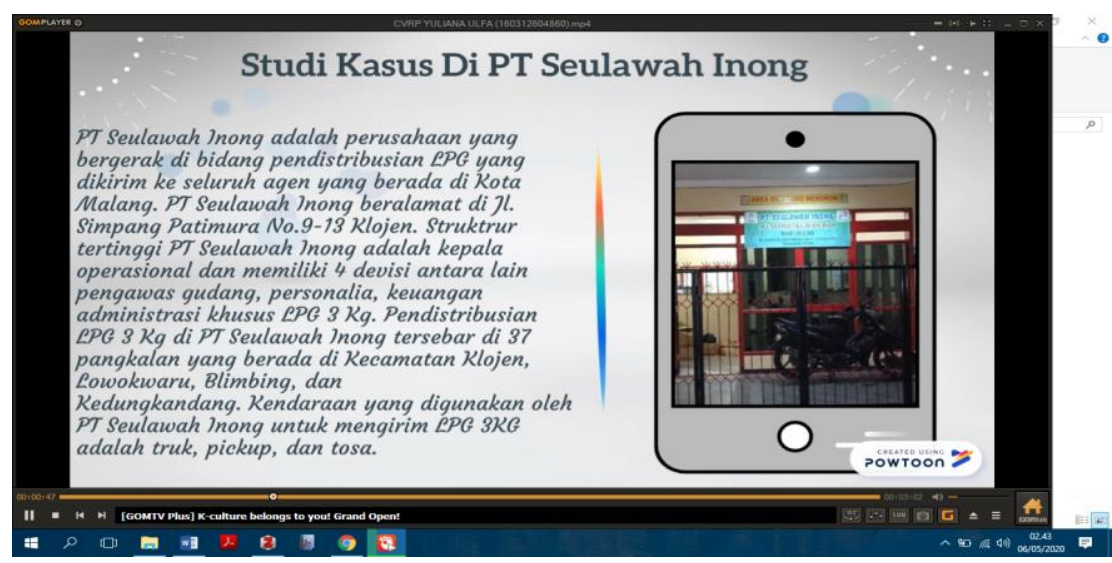

Fig. 7. Building problems in field surveys

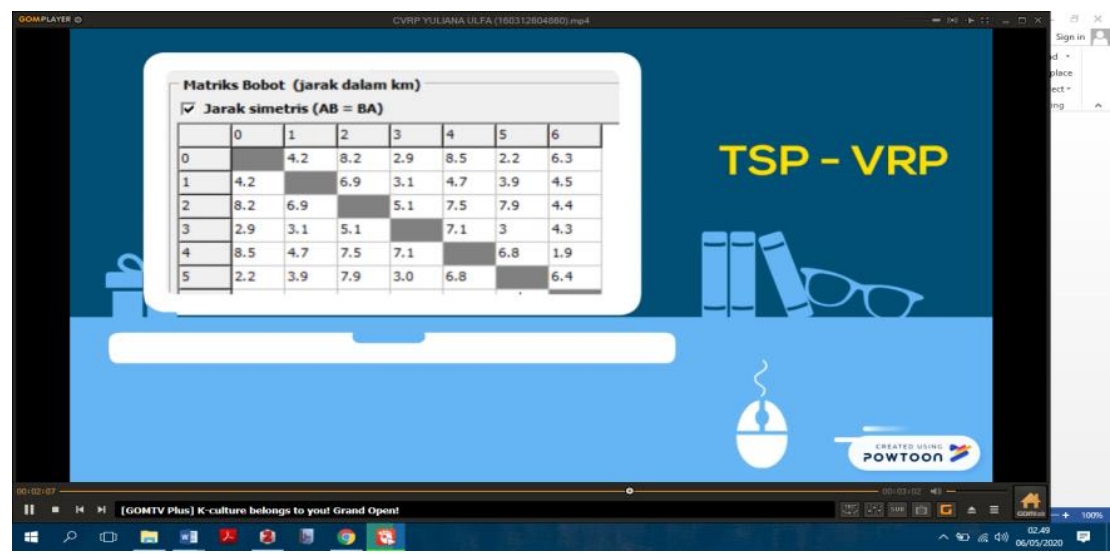

Fig. 8. Exploring real data 


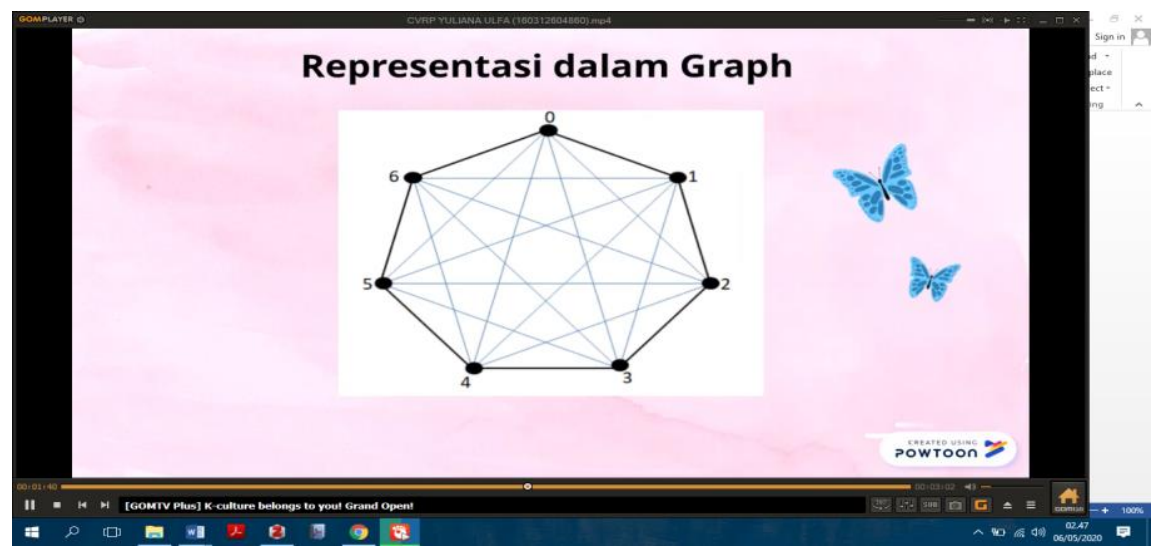

Fig. 9. Problem modeling

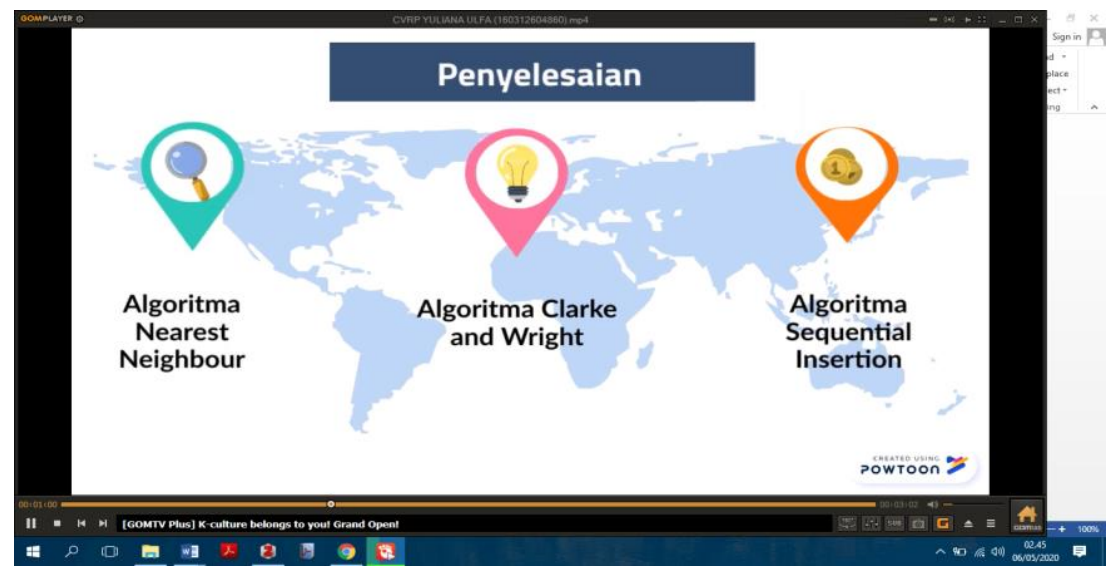

Fig. 10.Design solutions with algorithms

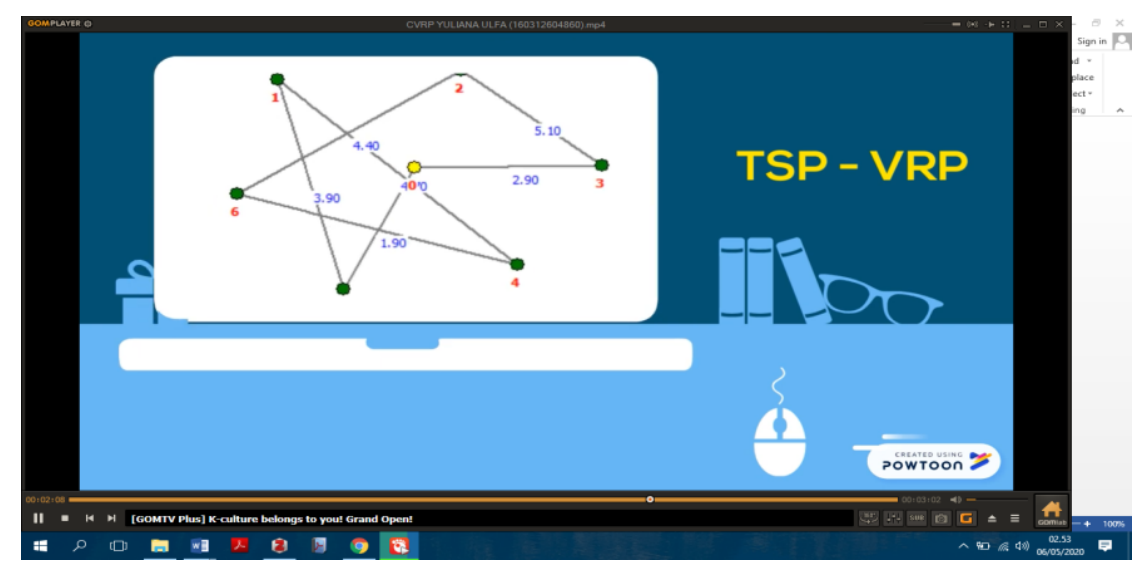

Fig. 11.Building acceptance of solutions 


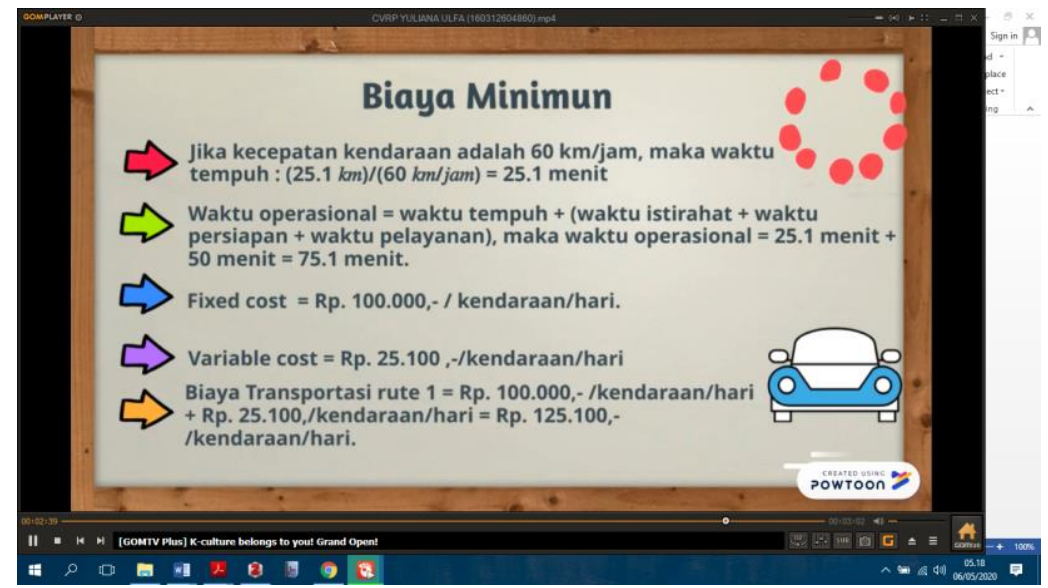

Fig. 12.Designing process solutions and their interpretation

Finding from this research is a significant improvement of students' Creative Problem-Solving by integrating learning the application of graph theory with "Online Interactive Apps". The statistics result with the application of the minitab program was found $\mathrm{p}<0.05$. This result shows that there is a significant increase in CPS mathematical performance of students by integrating an interactive online application.

These findings confirm the previous studies by [20], and [21]. Refer to the previous research: Engineering Education using web-based Interactive multimedia applications [31], interactive learning using digital assistance [32], the effect of web-based professional improve teachers' Problem Solving Strategies [20], effective integration of interactivity into future online courses [14], and Integrating mobile applications to improve creative thinking [25] these results support the idea of integrating learning with "Online Interactive Apps".

Student's creative problem solving through blended learning [22], effectiveness of m-learning applications for design and technology subject [33], problem solvers are better leaders: facilitating critical thinking among educators through online education [34] these results support the idea of students' Creative Problem-Solving by integrating learning upport the idea of integrating learning the application of graph theory with "Online Interactive Apps"

Significantly, The implementation of "Online Interactive Apps" based on kahoot and powtoon applications can be used as an alternative to disruptive learning innovation in mathematics teaching-learning.

\section{Conclusion}

This paper has argued that the kahoot application is one of the online applications as a fun evaluation tool for learning graph theory. In this investigation, we assess the provision of interactive application-based tasks such as the Powtoon application to improve creative problem solving performance. Integrating an online interactive app 
can improve the performance of creative problem solving math students. The criteria of the CPS version 6 used to identification of mathematics students in learning the application of graph theory. To confirm the result of CPS, a questionnaire was given to the students, and it can be described that $69 \%$ of students gave opinions of very agree on learning activity can improve creative problem solving.

It should also make recommendations for further studies or changes that should be made in practice. The integration of interactive online applications can be used for learning mathematics. The findings that has been discussed suggest that integration in online interactive learning applications in addition to powtoon applications such as visme, prezi, go animate, and emaze.

\section{Acknowledgement}

This article is part of Research Grant 4 in 1 IsDB Project year 2019 contract No. 26.3.24/UN32.14.1/LT/2019. Thank for PUIPT DLI (Disruptive Learning Innovation) Universitas Negeri Malang.

\section{$7 \quad$ References}

[1] D. Davis, G. Chen, C. Hauff, and G.-J. Houben, “Activating learning at scale: A review of innovations in online learning strategies," Comput. Educ., vol. 125, pp. 327-344, Oct. 2018, https://doi.org/10.1016/j.compedu.2018.05.019.

[2] N. A. Shukor, Z. Tasir, and H. Van der Meijden, "An Examination of Online Learning Effectiveness Using Data Mining,” Procedia - Soc. Behav. Sci., vol. 172, pp. 555-562, Jan. 2015, https://doi.org/10.1016/j.sbspro.2015.01.402.

[3] P. Deshwal, A. Trivedi, and H. L. N. Himanshi, "Online Learning Experience Scale Validation and Its Impact on Learners' Satisfaction," Procedia Comput. Sci., vol. 112, pp. 2455-2462, 2017, https://doi.org/10.1016/j.procs.2017.08.178.

[4] A. T. Baharin, H. Lateh, H. mohd Nawawi, and S. S. Nathan, "Evaluation of Satisfaction Using Online Learning with Interactivity," Procedia - Soc. Behav. Sci., vol. 171, pp. 905911, Jan. 2015, https://doi.org/10.1016/j.sbspro.2015.01.208.

[5] S. F. Persada, A. Oktavianto, B. Miraja, R. Nadlifatin, P. F. Belgiawan, and A. A. N. P. Perwira Redi, "Public Perceptions of Online Learning in Developing Countries: A Study Using The ELK Stack for Sentiment Analysis on Twitter,” Int. J. Emerg. Technol. Learn. IJET, vol. 15, no. 09, p. 94, May 2020, https://doi.org/10.3991/ijet.v15i09.11579.

[6] C. Wang, T. Fang, and Y. Gu, "Learning performance and behavioral patterns of online collaborative learning: Impact of cognitive load and affordances of different multimedia," Comput. Educ., vol. 143, p. 103683, Jan. 2020, https://doi.org/10.1016/j.compedu.2019.1 $\underline{03683}$.

[7] M. Pezzino, "Online assessment, adaptive feedback and the importance of visual learning for students. The advantages, with a few caveats, of using MapleTA," Int. Rev. Econ. Educ., vol. 28, pp. 11-28, May 2018, https://doi.org/10.1016/j.iree.2018.03.002.

[8] M. Friedl, M. Ebner, and M. Ebner, "Mobile Learning Applications for Android und iOS for German Language Acquisition based on Learning Analytics Measurements," Int. J. Learn. Anal. Artif. Intell. Educ. IJAI, vol. 2, no. 1, p. 4, Mar. 2020, https://doi.org/10.3991/ ijai.v2i1.12317 
[9] A.-E. Guerrero-Roldán and I. Noguera, "A model for aligning assessment with competences and learning activities in online courses," Internet High. Educ., vol. 38, pp. 36-46, Jul. 2018, https://doi.org/10.1016/j.iheduc.2018.04.005.

[10] I. N. Umar and A. S. A. Hassan, "Malaysian Teachers' Levels of ICT Integration and Its Perceived Impact on Teaching and Learning," Procedia - Soc. Behav. Sci., vol. 197, pp. 2015-2021, Jul. 2015, https://doi.org/10.1016/j.sbspro.2015.07.586.

[11] C. Chan, "Using digital storytelling to facilitate critical thinking disposition in youth civic engagement: A randomized control trial," Child. Youth Serv. Rev., vol. 107, p. 104522, Dec. 2019, https://doi.org/10.1016/j.childyouth.2019.104522.

[12] N. Parsazadeh, R. Ali, and M. Rezaei, "A framework for cooperative and interactive mobile learning to improve online information evaluation skills," Comput. Educ., vol. 120, pp. 75-89, May 2018, https://doi.org/10.1016/j.compedu.2018.01.010.

[13] K. A. Maboe, "Use of online interactive tools in an open distance learning context: Health studies students' perspective," Health SA Gesondheid, vol. 22, pp. 221-227, Dec. 2017, https://doi.org/10.1016/j.hsag.2017.02.001.

[14] H.-C. Wei, H. Peng, and C. Chou, "Can more interactivity improve learning achievement in an online course? Effects of college students' perception and actual use of a coursemanagement system on their learning achievement," Comput. Educ., vol. 83, pp. 10-21, Apr. 2015, https://doi.org/10.1016/j.compedu.2014.12.013.

[15] L. Costică, "The Contribution of the New Technologies to Learning Mathematics," Procedia - Soc. Behav. Sci., vol. 128, pp. 240-245, Apr. 2014, https://doi.org/10.1016/j.sbs pro.2014.03.150

[16] Z. Taleb, A. Ahmadi, and M. Musavi, "The Effect of M-learning on Mathematics Learning," Procedia - Soc. Behav. Sci., vol. 171, pp. 83-89, Jan. 2015, https://doi.org/10. 1016/j.sbspro.2015.01.092.

[17] J. Robová, "The Impact of Web Sites on Teaching and Learning Mathematics," Procedia Soc. Behav. Sci., vol. 93, pp. 631-635, Oct. 2013, https://doi.org/10.1016/j.sbspro.2013. 09.252.

[18] S. Wahyuningsih, D. Satyananda, L. T. Octoviana, and R. Nurhakiki, "Implementation of Creativity Problem Solving Model Using E-Learning in Applied Graph Theory Course," J. Phys. Conf. Ser., vol. 1227, p. 012017, Jun. 2019, https://doi.org/10.1088/17426596/1227/1/012017.

[19] R. A. Harrington, L. Burton, and C. Beaver, "Answering the call by developing an online elementary mathematics specialist program," J. Math. Behav., vol. 46, pp. 303-312, Jun. 2017, https://doi.org/10.1016/j.jmathb.2017.01.001.

[20] A. Pusmaz and A. S. Ozdemir, "The Effect of Web-based Professional Development Study to Mathematics Teachers' Problem Solving Strategies," Procedia - Soc. Behav. Sci., vol. 46, pp. 1380-1384, 2012, https://doi.org/10.1016/j.sbspro.2012.05.306.

[21] S. Sophonhiranrak, P. Suwannatthachote, and S. Ngudgratoke, "Factors Affecting Creative Problem Solving in the Blended Learning Environment: A Review of the Literature," Procedia - Soc. Behav. Sci., vol. 174, pp. 2130-2136, Feb. 2015, https://doi.org/10.1016/j. sbspro.2015.02.012.

[22] H. Kashefi, Z. Ismail, and Y. M. Yusof, "Supporting Engineering Students' Thinking and Creative Problem Solving through Blended Learning," Procedia - Soc. Behav. Sci., vol. 56, pp. 117-125, Oct. 2012, https://doi.org/10.1016/j.sbspro.2012.09.638.

[23] E. P. Brooks, N. Borum, and T. Rosenørn, "Designing Creative Pedagogies Through the Use of ICT in Secondary Education," Procedia - Soc. Behav. Sci., vol. 112, pp. 35-46, Feb. 2014, https://doi.org/10.1016/j.sbspro.2014.01.1137. 
[24] S. Sitti, S. Sopeerak, and N. Sompong, "Development of Instructional Model based on Connectivism Learning Theory to Enhance Problem-solving Skill in ICT for Daily Life of Higher Education Students," Procedia - Soc. Behav. Sci., vol. 103, pp. 315-322, Nov. 2013, https://doi.org/10.1016/j.sbspro.2013.10.339.

[25] H. E. Rudyanto, A. Ghufron, and H. Hartono, "Use of Integrated Mobile Application With Realistic Mathematics Education: A Study to Develop Elementary Students' Creative Thinking Ability,” Int. J. Interact. Mob. Technol. IJIM, vol. 13, no. 10, p. 19, Sep. 2019, https://doi.org/10.3991/ijim.v13i10.11598.

[26] T. Chuchu and T. Ndoro, "An Examination of the Determinants of the Adoption of Mobile Applications as Learning Tools for Higher Education Students," Int. J. Interact. Mob. Technol. IJIM, vol. 13, no. 03, p. 53, Mar. 2019, https://doi.org/10.3991/ijim.v13i03.101 $\underline{95}$.

[27] K. Shulamit and E. Yossi, "Development of E-Learning environments combining learning skills and science and technology content for junior high school," Procedia - Soc. Behav. Sci., vol. 11, pp. 175-179, 2011, https://doi.org/10.1016/j.sbspro.2011.01.056.

[28] C. Pélissier and S. M.-V. Metz, "Deviating technologies to design personal and creative help in e-learning," Procedia - Soc. Behav. Sci., vol. 2, no. 2, pp. 3552-3557, 2010, https:// doi.org/10.1016/j.sbspro.2010.03.550.

[29] A. Hajiyakhchali, "The Effects of Creative Problem Solving Process Training on Academic Well-being of Shahid Chamran University Students," Procedia - Soc. Behav. Sci., vol. 84, pp. 549-552, Jul. 2013, https://doi.org/10.1016/j.sbspro.2013.06.602.

[30] M. A. Kandemir and H. Gür, "The use of creative problem solving scenarios in mathematics education: views of some prospective teachers," Procedia - Soc. Behav. Sci., vol. 1, no. 1, pp. 1628-1635, 2009, https://doi.org/10.1016/j.sbspro.2009.01.286.

[31] D. Nickchen and B. Mertsching, "Combining Mathematical Revision Courses with Handson Approaches for Engineering Education using Web-Based Interactive Multimedia Applications," Procedia - Soc. Behav. Sci., vol. 228, pp. 482-488, Jul. 2016, https://doi.org/ 10.1016/j.sbspro.2016.07.074.

[32] H. Oestreich, T. Töniges, M. Wojtynek, and S. Wrede, "Interactive Learning of Assembly Processes using Digital Assistance,” Procedia Manuf., vol. 31, pp. 14-19, 2019, https://doi. org/10.1016/j.promfg.2019.03.003.

[33] S. A., S. Suhailiezana, C. G. Che Kob, and K. M, "Effectiveness of m-Learning Applications for Design and Technology Subject," Int. J. Interact. Mob. Technol. IJIM, vol. 13, no. 10, p. 120, Sep. 2019, https://doi.org/10.3991/ijim.v13i10.11324.

[34] K. Green and C. Jax, "Problem solvers are better leaders: facilitating critical thinking among educators through online education," Procedia - Soc. Behav. Sci., vol. 15, pp. 727730, 2011, https://doi.org/10.1016/j.sbspro.2011.03.173

\section{Authors}

Sapti Wahyuningsih is an associate professor at Faculty Science, and Mathematics, Universitas Negeri Malang. Her research interests include applied mathematics and disruptive learning innovations in higher education. Email: sapti.wahyuningsih.fmipa@um.ac.id,

Darmawan Satyananda is a senior lecturer at Faculty Science, and Mathematics, Universitas Negeri Malang. His research interests include graph application and computing method in distribution process. Email: darmawan.satyananda.fmipa@um.ac.id 
Abd Qohar is an associate professor at Faculty Science, and Mathematics, Universitas Negeri Malang. His research interests include Mathematics education, IT based learning and curriculum development. Email: abd.qohar.fmipa@um.ac.id

Noor Azean Binti Atan is senior lecturer, Department of Science, Mathematic Education and Creative Multimedia Faculty of Education, Universiti Teknologi Malaysia. Her research interests include Creative and Innovative Technologies in Education. Email: azean@utm.my

Article submitted 2020-04-14. Resubmitted 2020-05-17. Final acceptance 2020-05-18. Final version published as submitted by the authors. 